\title{
UNIVERSITY HERITAGE AS AN INSTRUMENT FOR THE DEVELOPMENT OF THE UNIVERSITY BRAND
}

\section{SVITLANA MURAVSKA - IVAN STASIUK}

\section{ABSTRACT/ABSTRAKT:}

Nowadays, the universities as social institutions are in crisis therefore they transform its activity and applies all possible means in the year-on-year the increasingly fierce competition for students. University heritage has recently begun to be valued as a tool in such activities. Museums and collections, including museums of university history, physical space and intangible heritage are all elements that have a special influence on the formation of a vision about the university.

This article examines the strengths of university heritage in higher education institution policies to attract students as well as how universities in 7 regions in the western part of Ukraine use their heritage to promote, advertise and make a unique university brand.

\section{Univerzitní dědictví jako nástroj pro rozvoj univerzitní značky}

Univerzity jako společenské instituce $\mathrm{v}$ současnosti procházejí krizí. Mění proto své aktivity a nasazují všechny dostupné prostředky, aby uspěly v dlouhodobém nelítostném konkurenčním boji o studenty. $\mathrm{V}$ poslední době začalo být univerzitní dědictví vnímáno jako užitečná pomůcka $\mathrm{v}$ rámci těchto aktivit. Muzea a sbírky, včetně muzeí univerzitní historie, fyzické prostory a nehmotné dědictví představují prvky, které mají specifický vliv na formování obrazu univerzity. Článek se zabývá významem univerzitního dědictví v rámci strategie institucí vyššího vzdělávání při získávání studentů a prezentuje způsob, jakým univerzity v sedmi regionech na západě Ukrajiny využívají své dědictví na podporu, propagaci a vytváření jedinečné univerzitní značky.

\section{KEYWORDS/KLIIČOVÁ SLOVA:}

university heritage - museum collection - intangible cultural heritage - university brand univerzitní dědictví - muzeum sbírka - nehmotné kulturní dědictví - univerzitní značka

\section{Introduction}

Although the discussion of mankind's past through the prism of its tangible and intangible heritage became more relevant several decades ago, attention to the heritage that had been formed in the higher education environment was more prevalent later. ${ }^{1}$ Key milestones in this process were the creation of the European University Heritage

\footnotetext{
1 See more: LOURENCO, Marta C. Between two worlds: the distinct nature and contemporary significance of university museums and collections in Europe [online]. Paris: Conservatoire National des Arts et Métiers, 2005 [accessed 2020-07-12]. Available from: <http://webpages.fc.ul. pt/ mcLourenco/chapters/MCL2005.pdf > PhD thesis; KOZAK, Zenobia R. Promoting the past, preserving the future: British university heritage collections and identity marketing [online]. St Andrews: University of St. Andrews, 2007. [accessed 2020-07-12]. Available from: <http://research-repository.st-andrews.ac.uk bitstream/10023/408/7/ZenobiaKozakPhDThesis. pdf $>$. PhD thesis. From 2016 Marta C. Lourenço is the Chair of UMAC.
}

https://doi.org/10.5817/MuB2020-2-1

Network Universeum and the Committee of University Museums and Collections at International Council of Museums (UMAC ICOM). Universeum initiated the signing of the Declaration of Halle in 2000. It has highlighted the importance of universities primarily as cultural centres. The university museums and collections were identified as special tools that make familiarization and participation in the life of higher education possible. It is equally important that this document has emphasized the importance of museums and collections in defining and interpreting the university cultural identity. $^{2}$

The emphasis on the importance of the higher education heritage is primarily due to the need to protect it taking into consideration the processes of optimization of university activities and the growth of requirements to all the organization departments. Marta Lourenço pointed out the demographic crisis, the increasingly fierce competition for students and the decline in public funding as the main reasons for this policy. ${ }^{3}$

\footnotetext{
2 The Declaration of Halle, 16 April 2000. In Universum, European University Heritage Network [online]. [accessed 2020-07-12]. Available from: $<$ https://www.universeum-network.eu/thedeclaration-of-halle/ $>$.

3 LOURENÇO, Marta C. Between two worlds: the distinct nature and contemporary significance of university museums and collections in Europe [online] Paris: Conservatoire National des Arts et Métiers, 2005, p. 124 [accessed 2020-07-12]. Available from: $<$ http://webpages.fc.ul.pt/ mcLourenço/chapters/ MCL2005.pdf $>$. PhD thesis.
} 
The university as a phenomenon was modified, became an innovative, service, corporate, and entrepreneurial university depending on the models offered by Risto Rinna and Jenni Koivula. ${ }^{4}$ It shows also its dependence on the public in the foundation of its existence. ${ }^{5}$ Marek Kwiek describes the current situation as "the identity crisis of a modern university". ${ }^{6}$ To overcome it and to win in the fight against competitors, the institution must identify resources that will help build a new public image and contribute to the transformation of values.

That is why branding of educational activities has become a usual phenomenon in recent decades. Since its main purpose is to individualize university services and to help consumers identify them as different, special, unique ones, all possible resources are used for this purpose. The rich history of the university is traditionally defined as one of its strengths to build the brand identity. The cultural heritage as a product of interpretation of the historical background helps to fulfil this task more comprehensively.

\section{Museums and collections as part of a larger whole}

When in Europe the university museum crisis was actively discussed in the mid-1980s, in

4 RISTO, Rinne and Jenni KOIVULA. The Changing Place of the University and a Clash of Values: The Entrepreneurial University in the European Knowledge Society. A Review of the Literature. Higher Education Management and Policy, 2005, vol. 17, no. 3, p. 103.

5 BOYLAN, Patrick J. Museums and collections in relation to the heritage of the university. In

SANZ, Nuria and Sjur BERGAN (eds.). The Heritage of European Universities. Strasbourg: Council of Europe, 2002, p. 67.

6 KWIEK, Marek. Nacionalna derzhava, globalizaciya ta Universytet yak modernyj zaklad. Ideya universytetu: Antologiya, pid redakciyeyu Mariyi Zubrycz'koyi. L'viv: Tsentr humanitarnykh doslidzhen Lvivskoho natsionalnoho universytetu, 2002, p. 269. the USSR, and later in the postSoviet republics different issues related to the university museums activity were also discoursed more actively on the pages of scientific journals, although the term "crisis" was not used. While research and audits of university museums abroad have indicated radical changes in their functions over the past decades, in Ukraine there was still a stereotype mainly of the teaching function of such museums. The author's research visits to 40 institutions of higher education in seven regions of Ukraine in 2013-2017, analysis of activity of 166 museums and collections, were organized to check such statement. In the end, it was proved that a few museums continue to be parts of the learning and research process, but it doesn't refer to most of them. Data has shown that only a third determine the teaching as their main task. Research function of high school museums has also transformed over the past 30 years. It has been implemented more or less fully in museums with a long history - Ivan Franko Lviv National University, Yurij Fedkovych Chernivtsi National University, Uzhgorod National University and some others although the significance of this process is greatly exaggerated.

In 2001 Lyndel King wrote: "We were the last place in the museum world [...] that had the luxury to research the collection and to present exhibitions that did not have to be popular [...] We were part of an academic institution that funded us and protected us and, basically, did not pay much attention to how many people came through our doors. [...] That is changing in the United States. University museums have been thrown into the marketplace and we must compete for funding. We are becoming less university museums and more museums at universities. This is not necessarily bad, but it does provide challenges."7

Since a university is a dynamic organization that is constantly evolving, one of the duties of the university museum is to reflect this dynamic. Z. R. Kozak defines this mission in the category of "responsibilities" in the universityto-museum relationship. "By recapturing the spirit of institutional identity and promotion previously mentioned, university museums have the opportunity not only to display objects and collections unique to their institutions, but also to use them to illustrate their university story. As previously stated, university museums have the potential to provide innovative services that immediately benefit the university in terms of institutional awareness and promotion, but also provide the wider audience with the distinctively academic and experimental programs only a university museum can provide." 8

Over 80 years ago Aute Richards wrote: "Good college and university museums are found in the whole in the good colleges and universities. [...] To be sure not every one campus museum units in the United States marks a progressive institution, but the colleges and the universities having are as the class the top and institutions with no museums at all are in the class of the backwards colleges". ${ }^{9}$

\footnotetext{
7 KING, Lindel. University museums in the 21th century - opening address. In KELLY, Melanie (ed.). Managing University Museums. Education and skills. Paris: Organisation for economic cooperation and development, 2001, p. 22. 8 KOZAK, Zenobia R. The Role of University Museums and Heritage in the 21st Century. The Museum Review [online]. 2016, vol. 1, no. 1, p. 6 [accessed 2020-07-12]. Available z www: < http://articles.themuseumreview.org/ vol1no1kozak>

9 RICHARDS, Aute. The University Museum of Zoology and Cultural Progress. Chronicles of Oklahoma [online]. 1942, vol. 20, no. 3, p. 266 [accessed 2020-07-12]. Available from www: <https://cdm17279.contentdm.oclc.org/ digital/collection/p17279coll4/id/30868/rec/97>.
} 
60 years later American museologist P. Tirrell's opinion on this topic has not changed: "Great universities have great museums!". ${ }^{10}$ This statement in the concept can be distinguished oppositely: if a university has an outstanding museum, the university is also an outstanding one. After all, only an institution with a clear development strategy and significant achievements sees the museum (museums) as a translator of its values and makes investments in those resources. The museum is an indicator of the success and prestige of the university, part of its public propaganda, a way to serve the interests of society. ${ }^{11}$ If the university is evaluated as an educational enterprise, according to S. Orekhova's opinion, a museum becomes an effective means of implementing communicative policy. ${ }^{12}$ Thus, all new opportunities of the university museum become its strong points and help the university to realize its third mission.

\section{Museums of university history: logical/illogical nature of their origin}

Alan MacGregor argued that "until the very end of the 16th century at the earliest, it was simply inconceivable that such a device [the museum] might find a place in the curriculum and it took several centuries more before museums

\footnotetext{
10 TIRRELL, Peter B. Dealing with change: university museums of natural history in the United States. Museum International, 2000, vol. 52 , no. 3 , p. 20 .

11 MACK, Vanessa. The dual Role of University Museums: Its Influence on Management. In KELLY, Melanie (ed.). Managing University Museums. Education and skills. Paris: Organisation for economic cooperation and development, 2001, p. 34

12 OREKHOVA, Svetlana E. Muzej kak sredstvo formy'rovany'ya korporaty'vnoj kul'tury y' realy'zacy'y' kommuny'katy'vnoj poly'ty'ky' predpry'yaty'ya (na pry'mere ukray'nskogo predpry'yaty'ya (na pry'mere ukray'nskogo
gosudarstvennogo predpry'yaty'ya pochtovoj svyazy' "Ukrpochta". Journal of Mariupol State University, Series: Philosophy, Culture Studies, Sociology, 2012, no. 3, p. 83.
}

found an undisputed role in the university milieu". ${ }^{13}$ Quoting these words Marta C. Lourenço points out different levels of responsibility of the university in the use of collections in the educational and research process and the creation of the museum. ${ }^{14}$

As in Maslow's hierarchy, the need for social connections becomes tangible once physiological and security needs are satisfied, a key point that emphasizes the necessity and logic of establishing a museum of university history comes only when the administration has defined a clear mission of the university in the educational space. Although, the plan for establishing university museums varies according to the purpose, the willingness of the universities authorities to take this step is a determining factor. Meanwhile, the logical development of this process and the creation of fullfledged museums, designed to transmit university values and to develop the university brand, is possible only in a democratic state system.The following example supports this idea, although other studies and examples are definitely needed to make this fact scientifically proven.

In the late 50s-early 60s in the Ukrainian Soviet Socialistic Republic, when fundings for culture were cut, the state authorities were promoting the creation of museums voluntarily, also in universities. Such museums were additional tools for promoting Soviet ideology.

\footnotetext{
13 MACGRECOR, Alan. University museums: were they ever worth it?. Whipple Museum, University of Cambridge, 4-6 July 2003. Unpublished paper presented at the Conference "University collections: are they worth it?".

14 LOURENÇO, Marta C. Between two worlds: the distinct nature and contemporary significance of university museums and collections in Europe [online]. Paris: Conservatoire National des Arts et Métiers, 2005, p. 65 [accessed 2020-07-12]. Available from: <http://webpages.fc.ul. pt/ mcLourenço/chapters/MCL2005.pdf $>$. PhD thesis.
}

That's why in the 60s-70s there was a peak in the formation of museums of higher education history - 39 out of 54 museums were created in this period. Morever, having analyzed the information about 300 university museums and collections formed after 1945, we have the following data: about a quarter of them were created as a result of government orders and they were usually dedicated to the anniversary of Victory in World War II and the October Revolution of 1917 in the Soviet Union. This factor used to influence the museum development negatively. Usually such museums were like "visiting rooms" for guests and didn't organize meaningfull museum activity. ${ }^{15}$

Another reason to establish museums compulsorily was the celebration of the anniversary of the higher school and the authorities willigness to present its history due to this date. ${ }^{16}$ Thus the museums of university history were formed as a separate type of museums. In Ukraine, over $15 \%$ of all museums (after 1945) were formed in such way.

\section{Strengths of university museums}

There are a lot of strengths of university museums that might encourage people to visit the higher education space and to help the higher education institution to fulfill its third mission as platform for links with its surrounding communities. Firstly, it reflects the academic cultural heritage andits

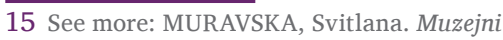
zaklady' u sy'stemi vy'shhoyi osvity' Zaxidnoyi Ukrayiny' na tli svitovy'x tendencij. L'viv: Tsentr pam'yatkoznavstva NAN Ukraïni i UTOPIK, 2018. 16 LOURENÇO, Marta C. Between two worlds: the distinct nature and contemporary significance of university museums and collections in Europe [online]. Paris: Conservatoire National des Arts et Métiers, 2005, p. 80 [accessed 2020-07-12]. Available from: <http://webpages.fc.ul. pt/ mcLourenço/chapters/MCL2005.pdf >. PhD thesis.
} 
past as well as shows its prestige. Secondly, using the museum potential in activities outside the academic environment provides an opportunity to promote its unique history and values alongside cultural events in the city, region and country as a whole, thus presenting the higher school to the public. ${ }^{17}$ The example of the Museum of Louvain-la-Neuve (Catholic University of Louvain) shows it is not so important where the museum is located, on-campus or not, its relationships with the public outside the university are far more important. The museum becomes an instrument that demonstrates the openness of the university to the outside world. ${ }^{18}$

An essential factor is that a museum of higher education institutions forms a special advertising product. It can be offered to entrants as part of career guidance work free of charge. Museums are the place where a student establishes connections with the academic environment for the first time, gets into the closed world, and the museum tour is not the only way there. Abstracting from potential students, university museums are an open door for collective access to the institution with a special atmosphere, a way to dispel the myths of the hosting institution to the public, whose representatives often have no other opportunity to contact the university. ${ }^{19}$

\section{Reload of university museums}

In recent years, communities at many universities around the world have significantly increased their work towards the use of

\footnotetext{
17 MARET, Pierre de. Exposing the Ivory Tower. Opuscula Musealia, 2006, vol. 15, p. 81.

18 DRIESSCHE, Bernard van den. University and Universality in Belgium. Museum International, 2000, vol. 52, no. 3, p. 44.

19 SIMPSON, Andrew. Integrating university museums into Museum Studies programs.

Opuscula Musealia, 2006, vol. 15, p. 88.
}

cultural heritage. David Ellis, Director of Museum and Cultural Relations at the University of Sydney, in the response to the email of Carolin Butler-Palmer, the assistant professor from University of Victoria, which was resent to all the UMAC members (dated 30 April 2018), pointed out that in 2013 he rewieved top 50 universities ${ }^{20}$ on the Jiao Tong ranking list. Its purpose was to analyze the latest investments in their museums as the University of Sydney has been planning to create a business case for a new museum. It was explicated that $90 \%$ (45) out of 50 universities had museums (more than one in most cases) within their organization and at least 12 of them have invested profoundly in the fundamental works related to improvement/ change of the infrastructure of their museums or galleries during last 10-15 years.

The assessment of cultural heritage as a resource for the development of a university brand is a relatively new phenomenon for Ukrainian higher education institutions. Meanwhile, the transformation processes in the system of higher education, since Ukraine has declared its independence, require proactive approaches from the universities authorities because of the increasing competition for the applicants. Although the process cannot be called a mass one, rectors of a lot of Ukrainian universities gradually recognize the importance of a third mission implementation by the university and regard cultural heritage as a mean for this purpose.

Establishment of new museums, reorganization of old ones, reconstruction of museum premises are the next arguments confirming

\footnotetext{
20 Formed by Shanghai Ranking Consultancy, which has been the official publisher of the Academic Ranking of World Universities since 2009.
}

the relevance of such decisions. In 2010 the Museum of History was founded in The Hetman Petro Sahaidachnyi National Ground Forces Academy. A separate building was rebuilt for this purpose in the centre of the university campus and is highly eye-catching. In 2011 after an almost 20-year break, the fully renovated Museum of History was opened in Ivan Franko Lviv National University. In the same year, the premises of the National University of Ostroh Academy Museum were renovated. In recent years this museum has confidently become one of the three most visited tourist sights in Ostroh. The university authorities plan to allocate a separate construction of the old monastery building for the museum and unite the academic heritage in one place. In Volodymyr Hnatiuk Ternopil National Pedagogical University the authorities attempt to unite all museums and collections into one complex. Although, this attempt looks somewhat artificial now, the process has started. Yurii Fedkovych Chernivtsi National University campus, the part of which is included in the UNESCO list of world cultural heritage sites, uses its physical space effectively to launch advertising campaigns, gradually involving museums in this activity. The Lviv Polytechnic National University administration has proposed the creation of the new museum at the premises of the machine laboratory ${ }^{21}$ and is actively fundraising for the project. Such random facts affirm the new stage of activity of university museums.

\section{Physical space as part of a brand}

A lot of universities are located in ancient buildings, architectural

\footnotetext{
21 The machine laboratory has a status of the monument of local culture importance. Its square more than $1000 \mathrm{~m}^{2}$.
} 
monuments, thus serving as reference points attracting visitors in general and tourists in particular. ${ }^{22}$ This part of the tangible university heritage is the most visible one. The dynamics of the university buildings being included to the UNESCO's list indicates that such status of university premises began to attract the interest of higher education administrators while developing university brands. There is an obvious coherence between these two phenomena.

Universities can be included into the UNESCO World Heritage List in two different ways: first, directly when a university (or part of it) is listed; second, indirectly, when the city center or site where the university is located is listed. According to the first point, universities represent only seven separate items on the UNESCO List, which now includes just over 1,000 items. Another almost 30 university buildings are included on the List as part of the historic cities where they are located. ${ }^{23}$ This status also affects the institution's brand. As an example, the University of Greenwich in South London joined the 17th-century buildings that previously belonged to Oxford and Cambridge because of their UNESCO status. According to P. J. Boylan, such actions indicated a desire to raise the prestige of universities. ${ }^{24}$

\footnotetext{
22 MARET, Pierre de. Exposing the Ivory Tower Opuscula Musealia, 2006, vol. 15, p. 81.

23 Universities World Heritage [online]. International Council of Museums, Committee for University Museums and Collections [accessed 2020-07-20]. Available from www: <http:// umac.icom.museum/resources/universities-worldheritage/>

24 BOYLAN, Patrick J. Museums and collections in relation to the heritage of the university. In SANZ, Nuria and Sjur BERGAN (eds.). The Heritage of European Universities. Strasbourg: Council of
} Europe, 2002, p. 67

\begin{tabular}{|l|c|c|}
\hline Location name & Country & $\begin{array}{c}\text { Year of inclusion } \\
\text { to UNESCO list }\end{array}$ \\
\hline Monticello and the University of Virginiain Charlottesville & USA & 1987 \\
\hline Botanical Garden (Orto Botanico), University of Padua & Italy & 1997 \\
\hline University and Historic Precinct of Alcalá de Henares & Spain & 1998 \\
\hline Ciudad Universitariade Caracas & Venezuela & 2000 \\
\hline $\begin{array}{l}\text { Central University City Campus of the Universidad Nacional } \\
\text { Autónomade México }\end{array}$ & Mexico & 2007 \\
\hline Yurij Fedkovych Chernivtsi National University (main campus) & Ukraine & 2011 \\
\hline University of Coimbra Alta and Sofia & Portugal & 2013 \\
\hline
\end{tabular}

Tab. 1: List of university premises included in UNESCO list as a separate item

The University of Greenwich has been developing a university brand also by the building of new premises. The world-famous architects are invited for this purpose. Although in 2018 critics haven't highly appreciated the project combination of old buildings and new library, because the design was "not traditional enough" and at the same time "not bold enough". However, the fact is obvious - the building is a tool to bolster the school's reputation, as well as "expanding the discipline's boundaries". ${ }^{25}$

Campus architecture and landscape fundamentally influence the college brand. There is even the idea that architecture and the influence of the physical environment affect first impressions and lead to lasting memories - and these influences drive the power of the college brand. ${ }^{26}$ Although only subsequent research may prove or disprove this statement convincingly. But there are indisputable facts - universities compete one after another in cost of buildings; size (including the size or

\footnotetext{
25 Too many cooks spoil Greenwich University's $£ 80 \mathrm{~m}$ new building. In The Guardian [online]. [accessed 2020-07-20]. Available from www: <https://www.theguardian.com/ artanddesign/architecture-design-blog/2014/ sep/18/greenwich-university-new-buildingheneghan-peng $>$

265 ways architecture defines the university brand. In Building Design + Construction [online]. [accessed 2020-07-20]. Available from www: $<$ https://www.bdcnetwork.com/blog/5-waysarchitecture-defines-university-brand $>$.
}

rarity of the collections housed in the building or complex); architectural elements, including the fame of the architect, the style or importance of the architecture, or the materials and decorations used; and amenities and innovative features.

The National University of Ostroh Academy is one of the few higher education institutions in Ukraine, whose administration uses cultural heritage resources to promote the university brand, also forming new architecture on the campus. In 2007 the architects won the award for the project of the library in the National Architects' Contest. Since the early 2000 s the rectorate has been looking for sources of additional funds to complete the long-built construction. It has passed on from the city balance sheet because of lack of funds to finish. University authorities had managed to attract many sponsors, mainly from the Ukrainian diaspora. The new university building was opened in 2019 and has the potential to become an adornment of central part of the city. Authorities strive for an ambitious combination of material and non-material cultural traditions of the city and the academy - in the XVI-XVII centuries this cultural centre was known as "Volyn Athens". Rector I. Pasichnyk considers: "In fact, the tower of the new building is the City Hall. In the morning there will be a melody of the student hymn Gaudeamus. It will 
notify students about the beginning of classes. The Beethoven's 'Ode to Joy' will be signal about the end of training activities. The construction of the City Hall is a kind of gift for Ostroh and it also symbolizes that the former capital city with Magdeburg law is regaining its glory". ${ }^{27}$

\section{University cultural heritage: something more than visible}

Besides museums and collections, which are traditionally associated with the university cultural heritage, intangible heritage is its separate link. Since intangible cultural heritage means the practices, representations, knowledge, skills - as well as the instruments, objects, artefacts and cultural spaces associated there with - it has a specific meaning for universities. In 2008 Lars Burman, the vice-chancellor for culture and traditions at the Uppsala University, has expanded the concept of university cultural heritage and denied association this word only with collections accumulated over the centuries. ${ }^{28}$ According to L. Burman's point of view, "Cultural heritage is not just an object to being cared for, it is part of a larger whole. It's about our identity, our traditions and our way of thinking". ${ }^{29}$ He has also emphasized that cultural heritage is now a strategic resource for the university, while culture, cultural environment, valuable monuments and cultural heritage, in general, are the basic pillars

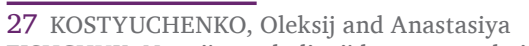
FISHCHUK. Novy'j navchal'ny'j korpus urochy'sto vidkry'to ! In Nacional'ny'j universy'tet “Ostroz'ka akademiya" [online]. [accessed 2020-07-20]. Available from www: < https://www.oa.edu.ua/ ua/info/news/2019/28-11-01>.

28 BURMAN, Lars. Att förvalta sitt pund. Om kulturarv och kultursstrategier vid Uppsala universitet [online]. Upssala: Uppsala universitet, 2008, p. 18 [accessed 2020-07-20]. Available from www: <https://uu.diva-portal. org/smash/get/diva2:128416/FULLTEXT01.pdf>

29 HULTH, Annica. Universitetets kulturarv mer än bara samlingar. In Uppsala Universitet [online]. 2009 [accessed 2020-07-20]. Available from www: <https://www.uu.se/nyheter-press/ nyheter/artikel/?id $=579 \&$ typ $=$ artikel $>$. of society. Although heritage development requires investment, it produces direct economic value in the form of goodwill for the university and helps build its brand. Moreover, it increases the confidence in the higher school and in the environment around it. ${ }^{30}$

Burman has pointed out that history, culture, and large collections give prestige and attract admiration. The university must benefit from such pros, for example, thorough organizing student recruitment. Cultural heritage makes the university more attractive for work and research. Therefore, the university policy on cultural heritage and the way it can be used to strengthen the position of the university in society is an essential target. Moreover, the peculiarities of marketing activity depend on the levels of implementation. Within the state, it makes sense to highlight what is unique in the university. But on the international educational market, it is reasonable to compare the university with other successful universities with a rich history. Academic heritage provides an opportunity to shape a special cultural environment, a kind of new investment. In such way, the university takes responsibility for its past. Therefore, the task of maintaining and developing identity and cultural heritage is an important part of Uppsala University's strategic policy and a good role model. ${ }^{31}$ O. Dostál assesses the whole university as part of the intangible heritage: "A public university can be called a national cultural heritage, too. Public universities educate and employ scholars who are a crucial element of

\footnotetext{
30 BURMAN, Lars. Att förvalta sitt pund. Om kulturarv och kultursstrategier vid Uppsala universitet [online]. Upssala: Uppsala universitet, 2008, p. 11 [accessed 2020-07-20]. Available from www: < https://uu.diva-portal. org/smash/get/diva2:128416/FULLTEXT01.pdf>. 31 Ibidem, p. 50.
}

society and the creation of its values; values future generations lean on". ${ }^{32}$

It is the museum, as the unique university subdivision, that should play a special role in the process of intangible heritage preservation and demonstration. They should record events of academic and student life, inter-department relations, features of ceremonial dress etc. The museum should raise respect to the university traditions and cultivate a feeling of connection with the university community, promote a sense of collegial relationships. It is clear that not only the museum staff need to work to consolidate these emotions, but the museum's activity becomes one of the main factors. This task is realized by formation and keeping of research and learning traditions, popularization of information about famous alumni, storing and creation of university initiation ceremonies, organization of art events, etc. ${ }^{33}$

This way, it ensures the continuity of university traditions and the connection of the university's past with the future through the interpretation of socio-cultural, scientific and educational university experience in the present. Some credits on university history is a good tool to promote university identity development. The example of course "History of Ostroh Academy" in the National University of Ostroh Academy testifies the university museum can become the centre for the organization of learning activity.

\footnotetext{
32 DOSTÁL, Ondřej. Mendel Museum, the first university museum in the Czech Republic Short excursion to the history of university museums in the Czech Republic. University Museums and Collections Journal [online]. 2010, no. 3, p. 138. [accessed 2020-07-20]. Available from www: <https://edoc.hu-berlin. de/bitstream/handle/18452/9343/dostal. pdf? sequence $=1 \&$ isAllowed $=y>$.

33 BULOTAITE, Nijole. University heritage - an institutional tool for branding and marketing. Higher education in Europe, 2003, vol. 28, no. 4, pp. 449-454.
} 


\section{Conclusions}

New circumstances of the higher school activity, competition for the applicants stipulate intensive work of the universities to create and promote their own brands. Emphasizing the special role of university cultural heritage should become an integral part of this work. Although, these results don't have an immediate effect, they can yield long-lasting dividends.

After all, university heritage has a positive impact on the university reputation, including the attitude of potential students and the intention to pay tuition fees as well as to recommend the university. Moreover, it has a special effect on the programs of recruiting foreign students. ${ }^{34}$ Universities in Ukraine have recently started to use the university heritage as a resource to invigorate their brand. However, every year the cases of attracting this tool is growing. It allows not only to preserve the existing heritage, but also provides favourable conditions to create its new forms.

\section{BIBLIOGRAPHY:}

BOYLAN, Patrick J. Museums and collections in relation to the heritage of the university. In SANZ, Nuria and Sjur BERGAN (eds.). The Heritage of European Universities. Strasbourg: Council of Europe, 2002, pp. 67-73. ISBN 978-92-871-6121-5.

BULOTAITE, Nijole. University heritage an institutional tool for branding and marketing. Higher education in Europe, 2003, vol. 28, no. 4, pp. 449-454. ISSN 0379-7724. https://doi. org/10.1080/0379772032000170417

BURMAN, Lars. Att förvalta sitt pund. Om kulturarv och kultursstrategier vid Uppsala universitet [online]. Upssala: Uppsala

34 Effect of University Heritage and Reputation on Attitudes of Prospective Students. International Journal of Nonprofit and Voluntary Sector

Marketing [online]. 2014, vol. 20, no. 1 [accessed 2020-07-20]. Available from www: <https:// onlinelibrary.wiley.com/doi/full/10.1002/ nvsm.1515>. universitet, 2008. 52 p. [accessed 2020-07-20]. Available from www: <https://uu.diva-portal.org/smash/get/ diva2:128416/FULLTEXT01.pdf $>$. ISBN 978-91-506-2038-2.

DOSTÁL, Ondřej. Mendel Museum, the first university museum in the Czech Republic - Short excursion to the history of university museums in the Czech Republic. University Museums and Collections Journal [online]. 2010, no. 3, pp. 137-140 [accessed 2020-07-20]. Available from www: <https://edoc.hu-berlin.de/ bitstream/handle/18452/9343/dostal. pdf? sequence $=1 \&$ is Allowed $=y>$.

DRIESSCHE, Bernard van den. University and Universality in Belgium. Museum International, 2000, vol. 52, no. 3, pp. 38-44. ISSN 1350-0775.

https://doi.org/10.1111/1468-0033.00271

Effect of University Heritage and Reputation on Attitudes of Prospective Students. International Journal of Nonprofit and Voluntary Sector Marketing [online]. 2014, vol. 20, no. 1 [accessed 2020-0720]. Available from www: <https:// onlinelibrary.wiley.com/doi/full/10.1002/ nvsm.1515>. ISSN 1465-4520. https://doi.org/10.1002/nvsm.1515.

HULTH, Annica. Universitetets kulturarv mer än bara samlingar. In Uppsala Universitet [online]. 2009 [accessed 2020-07-20]. Available from www: <https://www.uu.se/nyheter-press/ nyheter/artikel/?id=579\&typ $=$ artikel $>$.

KING, Lindel. University museums in the 21th century - opening address. In KELLY, Melanie (ed.). Managing University Museums. Education and skills. Paris: Organisation for economic cooperation and development, 2001, pp. 19-28. ISBN 92-64-19524-6.

KOSTYUCHENKO, Oleksij and Anastasiya FISHCHUK. Novy'j navchal'ny'j korpus urochy'sto vidkry'to ! In Nacional'ny'j universy'tet “Ostroz'ka akademiya” [online]. [accessed 2020-07-20]. Available from www: $<$ https://www.oa.edu.ua/ua/info/ news/2019/28-11-01>.

KOZAK, Zenobia R. The Role of University Museums and Heritage in the 21st Century. The Museum Review [online]. 2016, vol. 1, no. 1, p. 6 [accessed 2020-07-12]. Available z www: <http:// articles.themuseumreview.org/ vol1no1kozak>. ISSN 2574-0296.

KOZAK, Zenobia R. Promoting the past, preserving the future: British university heritage collections and identity marketing [online]. St Andrews: University of St. Andrews, 2007. 279 p. [accessed 2020-07-12]. Available from: <http:// research-repository.st-andrews. ac.uk/bitstream/10023/408/7/ ZenobiaKozakPhDThesis.pdf $>$. PhD thesis.

KWIEK, Marek. Nacionalna derzhava, globalizaciya ta Universytet yak modernyj zaklad. Ideya universytetu: Antologiya, pid redakciyeyu Mariyi Zubrycz'koyi. L'viv: Tsentr humanitarnykh doslidzhen Lvivskoho natsionalnoho universytetu, 2002, pp. 269-291. ISBN 966-7007-68-4.

LOURENÇO, Marta C. Between two worlds: the distinct nature and contemporary significance of university museums and collections in Europe [online]. Paris: Conservatoire National des Arts et Métiers, 2005. 405 p. [accessed 2020-07-12]. Available from: < http:// webpages.fc.ul.pt/ mcLourenço/ chapters/MCL2005.pdf >. PhD thesis.

MACGRECOR, Alan. University museums: were they ever worth it?. Whipple Museum, University of Cambridge, 4-6 July 2003. Unpublished paper presented at the Conference "University collections: are they worth it?".

MACK, Vanessa. The dual Role of University Museums: Its Influence on Management. In KELLY, Melanie (ed.). Managing University Museums. Education and skills. Paris: Organisation for economic cooperation and development, 2001, pp. 29-37. ISBN 92-64-19524-6.

MARET, Pierre de. Exposing the Ivory Tower. Opuscula Musealia, 2006, vol. 15, pp. 77-83. ISSN 0239-9989.

MURAVSKA, Svitlana. Muzejni zaklady" u sy'stemi vy'shhoyi osvity' Zaxidnoyi Ukrayiny' na tli svitovy'x tendencij. L’viv: Tsentr pam'yatkoznavst va NAN Ukraïni i UTOPIK, 2018. 243 p. ISBN 978-966-8999-91-8.

OREKHOVA, Svetlana E. Muzej kak sredstvo formy'rovany'ya korporaty'vnoj kul'tury y' realy'zacy'y' kommuny'katy'vnoj poly'ty'ky' predpry'yaty'ya (na pry'mere ukray'nskogo gosudarstvennogo predpry'yaty'ya pochtovoj svyazy' "Ukrpochta". Journal of Mariupol State 
University, Series: Philosophy, Culture Studies, Sociology, 2012, no. 3, pp. 83-87. ISSN 2226-2849.

RICHARDS, Aute. The University Museum of Zoology and Cultural Progress. Chronicles of Oklahoma [online]. 1942, vol. 20, no. 3, pp. 265-274 [accessed 2020-07-12]. Available from www: < https://cdm17279. contentdm.oclc.org/digital/collection/ p17279coll4/id/30868/rec/97>.

RISTO, Rinne and Jenni KOIVULA. The Changing Place of the University and a Clash of Values: The Entrepreneurial University in the European Knowledge Society. A Review of the Literature. Higher Education Management and Policy, 2005, vol. 17, no. 3, pp. 91-122. ISSN 1682-3451. https://doi.org/10.1787/hemp-v17-art20-en
SIMPSON, Andrew. Integrating university museums into Museum Studies programs. Opuscula Musealia, 2006, vol. 15, pp. 85-92. ISSN 0239-9989.

The Declaration of Halle, 16 April 2000. In Universum, European University Heritage Network [online]. [accessed 2020-07-12]. Available from: < https://www.universeumnetwork.eu/the-declaration-of-halle/ $>$.

TIRRELL, Peter B. Dealing with change: university museums of natural history in the United States. Museum International, 2000, vol. 52, no. 3, pp. 15-20.

\section{ISSN 1350-0775.}

https://doi.org/10.1111/1468-0033.00267

Too many cooks spoil Greenwich University’s $£ 80 \mathrm{~m}$ new building. In The Guardian [online]. [accessed
2020-07-20]. Available from www: $<$ https://www.theguardian.com/ artanddesign/architecture-designblog/2014/sep/18/greenwich-universitynew-building-heneghan-peng $>$.

Universities World Heritage [online].

International Council of Museums,

Committee for University Museums and Collections [accessed 2020-07-20]. Available from www: < http://umac.icom. museum/resources/universities-worldheritage/ $>$.

5 ways architecture defines the university brand. In Building Design + Construction [online]. [accessed 2020-07-20]. Available from www: < https://www. bdcnetwork.com/blog/5-waysarchitecture-defines-university-brand $>$.

\section{SVITLANA MURAVSKA}

Department of History, Museology and Cultural Heritage, Lviv Polytechnic National University, Ukraine

svitlana.v.muravska@/pnu.ua

Associate professor in the Department of History, Museology and Cultural Heritage of Lviv Polytechnic National University. Her research interests focus on the history, theory and management of university collections and museums. Her book Museum institutions in the system of higher education of Western Ukraine against the background of world trends was published in 2018. For the last ten years, she is active in researching Museology and since 2019 she is D.Sc. in Historical Studies (specialization Museum and Heritage Studies). She has also worked in Museum of National University of Ostroh Academy (Ukraine) for 6 years. An ICOM member since 2013.

Svitlana Muravska je docentkou na Katedře historie, muzeologie a kulturního dědictví Lvovské polytechnické národní univerzity. Její výzkumná činnost se soustřed’uje na dějiny, teorii a management univerzitních sbírek a muzeí. V roce
2018 vyšla její kniha pod názvem Muzejní instituce v systému vyššího vzdělávání na západní Ukrajině na pozadí světových trendů. Posledních deset let se aktivně věnuje výzkumu $\mathrm{v}$ oblasti muzeologie a $\mathrm{v}$ roku 2019 získala titul doktor věd v oboru historie (se specializací na muzejnictví a studium kulturního dědictví). Šest let pracovala v Muzeu Národní univerzity Ostrožská akademie v Ostrohu (Ukrajina). Od roku 2013 je členkou ICOM.

\section{IVAN STASIUK}

Department of History, Museology and Cultural Heritage, Lviv Polytechnic National University, Ukraine

ivan.m.stasiuk@|pnu.ua

Associate professor in the Department of History, Museum Studies and Cultural Heritage of Lviv Polytechnic National University. For 15 years he has been teaching heritage tourism at the university courses. His research interests focus on the heritage tourism in Ukraine and abroad.

Ivan Stasiuk je docentem na Katedře historie, muzeologie a kulturního dědictví Lvovské polytechnické národní univerzity. Patnáct let přednášel na téma kulturního a památkového turizmu v rámci univerzitních kurzů. Jeho výzkumná činnost se soustřed’uje na oblast kulturního turizmu na Ukrajině a v zahraničí. 